\title{
Desain Sensor Massa Resonator MEMS Menggunakan Struktur Free- free Beam
}

\author{
Wangi P. Sari ${ }^{1}$ \\ ${ }^{1}$ Department of Mechanical and Industrial Engineering, Universitas Gadjah Mada, Indonesia \\ Email: wangipandansari@ugm.ac.id
}

Received: October 1, 2021; Accepted : October 9, 2021; Published : November 1, 2021

\begin{abstract}
ABSTRCT
MEMS (micro-electromechanical systems) is an integrated electro-mechanical device which the technology has been applied to various applications, one of which is for the fabrication of microsensors, such accelerometers, microsensors for flow sensing, pressure sensing and mass sensing. In the MEMS implementation, there are several approaches and structures that can be used. This study designed a MEMS resonator mass sensor by the means of a mechanical resonator approach with free-free beam structure and actuated electrostatically. The design is expected to produce a MEMS based mass sensor with a high performance.
\end{abstract}

Keywords: Design, Mass sensor, MEMS, Free-free Beam

\begin{abstract}
ABSTRAK
MEMS (micro-electromechanical systems) merupakan perangkat terintegrasi elektro-mekanik yang teknologinya telah diterapkan untuk berbagai aplikasi, salah satunya untuk fabrikasi mikrosensor seperti akselerometer, mikrosensor penginderaaan aliran, penginderaan tekanan, dan penginderaan massa. Dalam implementasi MEMS, terdapat beberapa pendekatan dan struktur yang dapat digunakan. Penelitian ini melakukan perancangan sensor massa resonator MEMS dengan menggunakan pendekatan resonator mekanik dengan struktur free-free beam yang diaktuasi secara elektrostatik. Desain yang dirancang diharapkan dapat menghasilkan sensor massa dengan performa yang tinggi.
\end{abstract}

Kata Kunci: Desain, Sensor massa, MEMS, free-free beam

\section{PENDAHULUAN}

Sistem mikroelektromekanis (MEMS) adalah perangkat terintegrasi kecil yang menggabungkan komponen elektrik dan mekanik. MEMS muncul dengan berkembangnya proses fabrikasi integrated circiut, di mana aktuator, sensor, dan fungsi kontrol digunakan untuk membuat sensor silikon, sehingga disebut mikrosensor. Pembuatan mikrosensor dengan teknologi mikrosistem menawarkan beberapa keuntungan termasuk penggunaan mikroteknologi yang mapan, produksi sensor miniatur dan sensor yang lebih kecil, produksi volume tinggi, dan integrasi prosesor [1]. Industri MEMS akan terus berkembang pesat dimana pertumbuhannya diproyeksikan akan meningkat dengan tingkat pertumbuhan tahun majemuk (CAGR) sebesar 7,4\% dari USD 11,5 miliar d tahun 2019 menjadi US\$17,7 miliar pada tahun 2025 [2].

Resonator MEMS bergetar pada frekuensi tinggi dan telah digunakan untuk berbagai aplikasi seperti penyaringan sinyal, penginderaan massa, penginderaan biologis, penginderaan gerak, dan lainnya. Beberapa contoh aplikasi yang menggunakan teknologi MEMS diantaranya sensor tekanan, akselerometer, dan sensor aliran gas. Sensor tekanan MEMS biasanya memiliki diafragma fleksibel yang berubah bentuk ketika ada perubahan tekanan. Deformasi diafragma dapat diukur menggunakan pengukur regangan piezoresistif yang terletak di wilayah regangan maksimum yang sesuai, seperti yang dapat dilihat pada Gambar 1. Pada sensor tekanan, terdapat dua pelat persegi berosilasi dan dikendalikan oleh pengikat berbentuk $\mathrm{v}$ yang dipasang pada dua tiang penyangga. Tekanan udara di bawah diafragma akan menyebabkan pilar bergerak ke atas dan terpisah, mengakibatkan peningkatan ketegangan pada ligatur sehingga menyebabkan frekuensi osilasi yang lebih tinggi. Resonator digerakkan secara elektrostatik dan osilasinya dideteksi secara kapasitif melalui elektroda logam pada dagu penyangga. Sensor ini dikembangkan oleh Greenwood dan kemudian dikomersialkan oleh Druck [3]. 


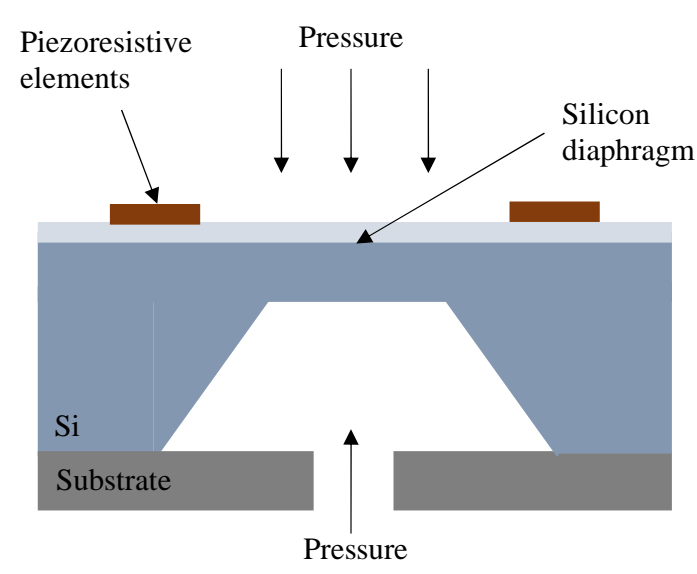

Gambar 1. Skematik sensor tekanan piezoresistive.

Contoh lainnya adalah akselerometer dimana massa inersia yang digantungkan oleh pegas dikenai gaya percepatan yang mengakibatkan massa berbelok dari posisi awalnya. Sensor ini didasarkan pada prinsip kantilever dengan engsel yang menahan massa (proof mass) seperti yang diilustrasikan pada Gambar 2.

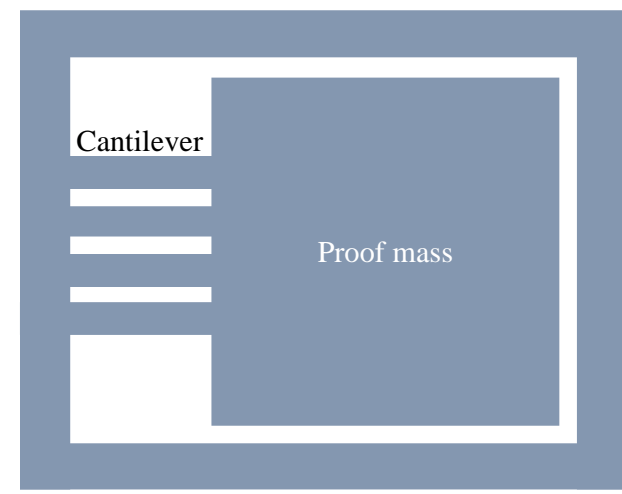

Gambar 2. Skematik akselerometer resonan.

Penelitian mengenai resonator MEMS untuk berbagai aplikasi sudah banyak dilakukan, diantaranya untuk mendeteksi analit dengan menggunakan kopel mikroresonator [4] dan mendeteksi aliran (flow sensing) dengan menggunakan struktur balok mikro double-clamped yang diaktuasi [5]. Berbagai riset juga sudah dilakukan untuk meneliti resonator MEMS sebagai akselerator, diantaranya adalah fabrikasi akselerometer MEMS dengan kinerja tinggi yang terdiri dari elemen bergetar yang diapit di antara dua massa inersia [6], fabrikasi dengan menggunakan struktur tumpuk tiga silikon-kaca-silikon yang didesain untuk meningkatkan performa akselerator resonator berbasis silikon untuk generasi selanjutnya [7], dan akselerometer yang dibuat dengan mode lokal yang menggunakan quasi-rigid couple [8]. Penelitian untuk meningkatkan performa akselerometer melalui investigasi mekanisme penginderaan baru juga telah dilakukan melalui pendekatan peningkatan berbasis osilator yang disinkronkan untuk meningkatkan resolusi sebanyak 5x lipat dari akselerometer resonansi mikroelektromekanis [9]. Resonator MEMS juga diaplikasikan untuk penginderaan massa contohnya dengan menggunakan struktur mikrokantilever yang digerakkan secara piezoelektrik [10, 11], struktur kopel kantilevel yang diaktuasi secara elektrostatik [12], struktur jepit tunggal (single-clamped) [13], dan struktur jepit dobel (clamped-clamped) [14]. Pada penelitian ini, resonator MEMS akan didesain untuk penginderaan massa dengan menggunakan struktur free-free beam.

\section{TEORI}

Pendekatan yang dapat dipakai untuk mengimplementasikan resonator MEMS meliputi mikromekanik dan akustik. Dalam mode mikromekanik, resonator membelok atau mengembang saat struktur bergetar sementara dalam pendekatan akustik, sinyal eksitasi dan sifat akustik resonator membuat gelombang dengan frekuensi yang sesuai merambat melalui bodi maupun permukaan.

\subsection{Resonator Mikromekanik}

Resonator mikromekanik merupakan struktur yang dapat digunakan untuk menyaring atau menghasilkan sinyal karena selektivitas frekuensinya yang tinggi [15]. Setiap struktur mekanik seperti balok 
kantilever, microbrigde, atau diafragma, memiliki frekuensi resonansi yang lebih tinggi dengan mengurangi dimensi resonator. Perilaku resonator bergerak dapat dinyatakan dalam osilasi harmonik teredam orde kedua dimana frekuensi resonansi dari resonator bergerak diberikan oleh:

$$
f_{n}=\frac{1}{2 \pi} \sqrt{\frac{k}{m_{e f f}^{n}}}
$$

Seperti yang terlihat dari persamaan (1), semakin kecil dimensi resonator menghasilkan nilai massa efektif yang lebih kecil sehingga meningkatkan frekuensi resonansi resonator.

Faktor kualitas $(\mathrm{Q})$ didefinisikan sebagai tingkat selektivitas dalam domain dan juga sama dengan rasio energi yang disimpan terhadap energi yang hilang per siklus [15]:

$$
Q=\frac{\Delta E_{\text {stored }}}{\Delta E_{\text {lost }}}
$$

Nilai Q yang tinggi memungkinkan sensitivitas gaya yang tinggi serta daya pengoperasian yang rendah. Ini juga menghasilkan penyisipan yang rendah karena disipasi rendah dan ini bagus untuk aplikasi frekuensi radio (RF). Oleh karena itu, semua sumber energi yang hilang harus diminimalkan agar memiliki Q-factor yang lebih tinggi. Dalam hal ini, Q-faktor dapat dimaksimalkan dengan meningkatkan kekakuan dan meminimalkan mekanisme redaman (D).

Aplikasi sensor dengan prinsip resonansi memberikan keuntungan seperti sensitivitas dan resolusi tinggi, noise rendah, dan output domain frekuensi. Namun, resonator dapat begeser karena sensitivitas suhu tinggi. Dalam hal ini diperlukan suatu mekanisme untuk mengkompensasi kondisi termal tersebut untuk mengatasi masalah tersebut.

Jenis read-out untuk mengubah defleksi menjadi listrik juga perlu dipertimbangkan. Jenis transduksi yang paling umum digunakan adalah kapasitif dan resistif. Menerapkan aktuasi elektrostatik balok kantilever dengan deteksi kapasitif membuat kantilever beresonansi ketika sinyal listrik AC dengan frekuensi yang sesuai diterapkan ke satu elektroda [16]. Elektroda pembacaan di sisi lain mengumpulkan arus transduksi kapasitif. dalam [16]:

Jenis read-out penting lainnya adalah menggunakan piezoresistif. Perilaku piezoresistif dinyatakan

$$
\Delta R \propto \frac{1}{2} \Pi \sigma
$$

Dimana $\mathrm{R}$ adalah perubahan nilai resistansi akibat deformasi piezoresistor, $\Pi$ adalah koefisien piezoresistif, dan $\sigma$ adalah tegangan pada struktur.

\subsection{Resonator Akustik}

Gelombang akustik adalah gangguan yang merambat dalam ruang dan waktu dalam bentuk osilasi dan dengan demikian mentransfer energi yang disuplai oleh sumber eksitasi [16]. Ada dua jenis gelombang akustik: gelombang akustik permukaan (SAW) dan gelombang akustik bulk (BAW). Untuk aplikasi sensor, berbagai jenis perangkat akustik terutama mencakup gelombang akustik permukaan Rayleigh, gelombang akustik permukaan shear horizontal (SH-SAW), gelombang Cinta, atau gelombang Lamb [1].

\subsubsection{Gelombang Akustik Permukaan Rayleigh}

Gelombang Rayleigh merupakan gelombang transversal yang merambat di sepanjang permukaan dan digambarkan dengan riak-riak yang tercipta di permukaan saat perahu bergerak. Substrat yang digunakan untuk jenis resonator akustik ini adalah ST-kuarsa dengan frekuensi tipikal $80-1000 \mathrm{MHz}$. Gangguan pada material kuarsa berasal dari interdigitated transducer (IDT) yang sinyalnya ditransfer melalui propagasi.

\subsubsection{Gelombang Akustik Shear Horizontal}

Partikel perpindahan gelombang akustik Shear Horizontal sejajar dengan bidang permukaan dan melintang terhadap arah rambat gelombang. Jenis gelombang sensitif terhadap beban massa, konduktivitas, viskositas, dan permitivitas cairan yang berdekatan. Substrat yang digunakan untuk SH-SAW adalah $\mathrm{LiTaO}_{3}$ dengan frekuensi tipikal $90-150 \mathrm{MHz}$.

\subsubsection{Gelombang Cinta}

Jenis gelombang berjalan lebih cepat dari gelombang Rayleigh dan gerakan partikelnya membentuk garis horizontal tegak lurus dengan arah rambat yang menciptakan gelombang geser terpolarisasi horizontal (gelombang shear horizontal). Pada dasarnya prinsip gelombang cinta sama dengan SH-SAW dengan 
perbedaan bahwa mode gelombang Cinta sama SH-SAW yang merambat pada lapisan yang diendapkan di atas IDT [1]. Gelombang cinta yang transversal, hanya membawa tegangan geser ke dalam aksi dan menggunakan ST-kuarsa sebagai substrat dengan frekuensi tipikal antara $95-120 \mathrm{MHz}$.

Resonator SAW (Gambar 3) pada dasarnya adalah rongga resonansi dengan dua atau lebih elektroda dan lapisan piezoelektrik dimana elektroda pertama mengubah sinyal listrik menjadi gelombang mekanik kemudian merambatkan SAW pada lapisan piezoelektrik untuk mencapai elektroda kedua [16]. Pada elektroda kedua, SAW yang dihasilkan dipantulkan kembali ke domain listrik dan konversi diulang tanpa batas.

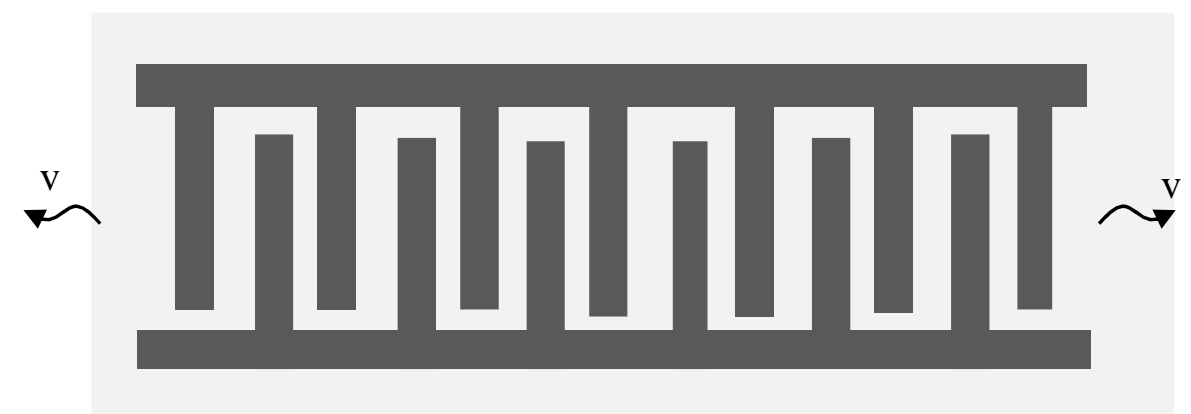

Gambar 3. Resonator gelombang akustis permukaan (surface acoustic wave - SAW).

\section{HASIL DAN ANALISIS}

Diantara berbagai struktur mikro untuk aplikasi sensor, struktur yang dipilih untuk sensor ini adalah free-free beam. Cantilever juga dapat digunakan untuk aplikasi ini, tetapi struktur cantilever dapat terdefleksi ke samping saat berosilasi sehingga menciptakan gerakan yang tidak diinginkan. Desain jepit (clamped design) dapat mengatasi masalah ini karena balok akan dijepit sehingga mengurangi kesalahan gerak. Namun, struktur free-free beam seperti yang terlihat pada Gambar 4 lebih menarik karena struktur ini menawarkan faktor kualitas $(Q$-factor) yang jauh lebih tinggi dibandingkan dengan jika menggunakan struktur balok klem ganda [17].

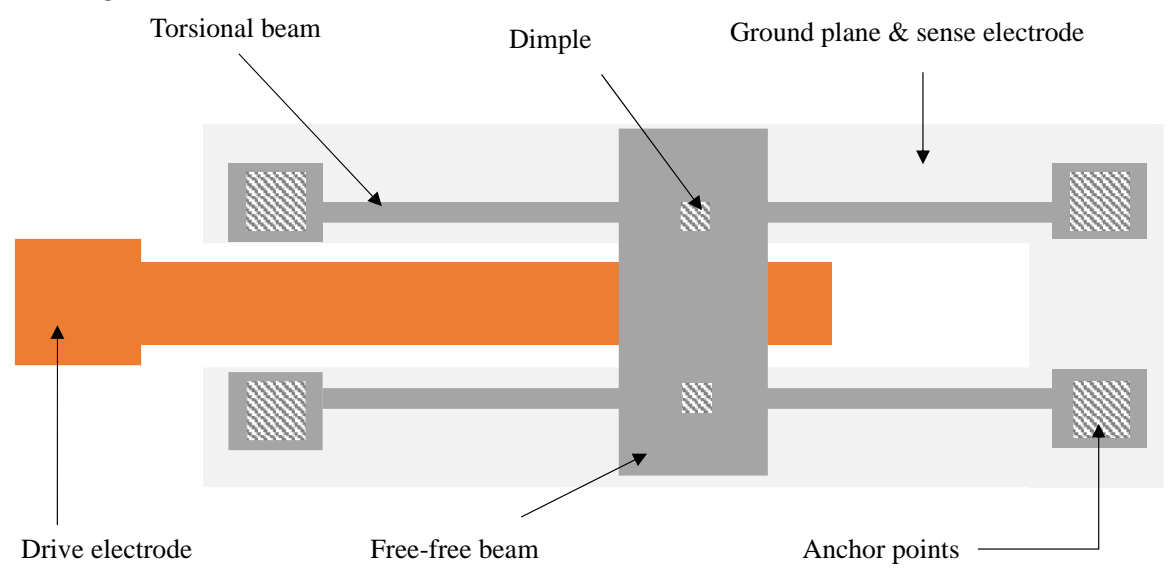

Gambar 4. Model resonator free-free beam.

\subsection{Konsep Desain}

Aplikasi yang diusulkan adalah sensor massa resonator MEMS yang dapat mendeteksi perubahan massa $1 \mathrm{ng}$ ke bagian area penginderaan pada perangkat yang dirancang. Dalam aplikasinya, setiap penambahan massa pada resonator mikromekanis akan meningkatkan massa efektif dan konstanta pegas yang mengakibatkan pergeseran frekuensi resonansi. Namun, resonator dapat dirancang sedemikian rupa sehingga frekuensinya hanya didominasi oleh perubahan massa. Frekuensi resonansi fundamental untuk free-free beam diberikan sebagai berikut [18] :

$$
f_{o}=1.03 \sqrt{\frac{E}{\rho}} \frac{T r}{L r^{2}}(\mathrm{~Hz})
$$

Dimana $L r, W r$, dan $T r$ adalah panjang, lebar, dan tebal balok bebas bebas. Dengan asumsi bahan yang digunakan untuk balok adalah silikon yang memiliki Young Modulus $\mathrm{E}=160 \mathrm{GPa}$ dan $=2330 \mathrm{~kg} / \mathrm{m}^{3}$, 
frekuensi resonansi balok dengan dimensi $100 \times 30 \times 2$ m untuk panjang, lebar, dan tebal masing-masing bisa dihitung:

$$
f_{o}=1.03 \sqrt{\frac{E}{\rho}} \frac{T r}{L r^{2}}=f_{o}=1.03 \sqrt{\frac{168.10^{9}}{2330}} \frac{2.10^{-6}}{\left(100.10^{-6}\right)^{2}}=1.75 e 6 \mathrm{~Hz}=1.75 \mathrm{GHz}
$$

Frekuensi resonansi balok tergantung pada panjang dan ketebalan balok. Adapun sensitivitas massa untuk berkas bebas bebas, hubungan antara massa dan perubahan frekuensi berbanding terbalik dengan massa seperti yang dinyatakan dalam persamaan berikut:

$$
\frac{d f}{d m}=\frac{1}{2 m} f
$$

Dengan menggunakan persamaan (5), sensitivitas massa $(m)$ untuk free-free beam untuk massa minimum yang dapat dideteksi dapat dihitung:

$$
\frac{d f}{d m}=\frac{1}{2 m} f=\frac{1}{2 \rho V} f=5.3624 e 16 \mathrm{~Hz} / \mathrm{kg}=\mathbf{5 3 . 6 2 4} \mathbf{~ k H z} / \mathbf{n g}
$$

Hal ini berarti dalam $1 \mathrm{ng}$ perubahan massa, frekuensi berubah sebesar 53,624 kHz. Jika massa minimum yang dapat dideteksi ingin dibuat lebih rendah, maka dimensi resonator mekanis perlu dikurangi. Namun, perubahan frekuensi minimum $d f$ tergantung pada gangguan fisik di dalam sistem. Ekinchi dkk. dalam [19] telah menentukan bahwa kebisingan termomekanis adalah salah satu faktor pembatas di mana:

$$
d f \cong \sqrt{\frac{k_{B} T B}{2 \pi \cdot m_{e f f(z)^{2} f Q}}}
$$

Dimana $\mathrm{Q}$ adalah faktor kualitas resonator, $k_{B}$ adalah konstanta Boltmann, $T$ adalah suhu, $z^{2}$ adalah amplitudo kuadrat rata-rata, dan B adalah pengukuran bandwidth. Parameter penting yang perlu dioptimalkan adalah factor $\mathrm{Q}$, yang didefinisikan sebagai akumulasi energi resonator dibagi dengan energi yang hilang dalam perangkat per siklus [17].

Free-free beam digerakkan secara elektrostatis, yakni dengna meletakkan elektroda pada permukaan substrat sehingga dapat berfungsi sebagai elektroda penggerak kapasitif untuk memungkinkan terjadinya aktuasi elektrostatik dalam arah tegak lurus substrat [18]. Beberapa metode deteksi yang tersedia untuk mendeteksi perubahan massa, seperti menggunakan metode pickup kapasitif, optik, dan piezoresistif. Bentuk transduksi yang paling umum digunakan adalah pickup kapasitif dan resistif. Pada desain ini, pickup yang dipilih adalah kapasitif karena metode ini menawarkan keuntungan seperti lebih kuat, lebih sensitif dan ketergantungan suhu kurang dibandingkan dengan piezoresistive [1]. Desain resonator free-free beam diilustrasikan pada Gambar 4.

Resonator terdiri dari balok berosilasi yang secara mekanis disokong oleh empat balok torsi. Masing-masing balok pendukung ditambatkan ke substrat dengan jangkar kontak kaku (anchor point). Elektroda ditempatkan di bawah balok osilasi yang berfungsi sebagai elektroda penggerak kapasitif untuk menggerakkan secara elektrostatik dengan arah tegak lurus terhadap substrat.

Menggunakan resonator free-free beam memungkinkan faktor kualitas yang lebih tinggi karena dapat menekan disipasi daya jangka pada resonator klem ganda (double clamped resonator). Balok pendukung torsi dirancang dengan dimensi seperempat panjang gelombang. Seperti yang diilustrasikan pada Gambar 4, resonator free-free beam ditopang pada titik-titik simpulnya (nodal points) oleh empat batang torsional. Posisi yang tepat dari titik-titik simpul dapat dihitung dengan menormalkan fungsi bentuk mode yang diberikan[18]:

$$
W_{(y)}=\cosh \left(\frac{4.73}{L_{r}}\right) y+\cos \frac{4.73}{L_{r}} y-0.9825\left(\sin \frac{4.73}{L_{r}} y+\sinh \frac{4.73}{L_{r}} y\right)
$$

Dimana $\left.W_{(y)}\right)$ adalah defleksi balok di titik y sepanjang panjang balok. Untuk balok dengan panjang $100 \mu \mathrm{m}$, perhitungan titik simpul didapatkan pada posisi pada $\mathbf{2 2 , 4 1} \boldsymbol{\mu m}$ ad 77,59 $\mu \mathrm{m}$.

Karena balok pendukung (torsional beam) dilekatkan pada titik simpul, balok tersebut tidak menanggung gerakan translasi selama osilasi resonator membuat losses pada anchor points sangat berkurang [20]. Selain itu, dengan memilih panjang balok pendukung seperempat panjang gelombang, transformasi impedansi mengisolasi free-free beam dari jangkar kaku [18].

Lebar balok penyangga Ws harus kecil untuk meminimalkan momen inersia polar yang dapat mengakibatkan pergerakan balok yang tidak diinginkan [18]. Untuk aplikasi ini, lebar Ws diatur menjadi 10 
$\mu \mathrm{m}$. Koefisien konstanta torsi $(\alpha)$ adalah rasio Ws dibagi dengan $\operatorname{Tr}: 10 / 1,25=6$. Untuk nilai 8, maka $\operatorname{Tr}$ akan menjadi 0,305. Panjang balok penyangga dapat dihitung dengan menggunakan rumus yang diberikan [21]:

$$
L s=\frac{1}{4 f} \sqrt{\frac{G \gamma}{\rho J s}}
$$

Dimana $\mathrm{G}$ adalah modulus geser Young, $\gamma$ adalah konstanta torsi, dan Js adalah momen inersia polar.

Dengan menggunakan persamaan (8), panjang balok penyangga dihitung menjadi $1,852 \mathrm{e}-4 \mathrm{~m}$ yang sama dengan $185 \mu \mathrm{m}$. Kalkulasi desain free-free beam secara keseluruhan dapat dilihat pada Gambar 5 .

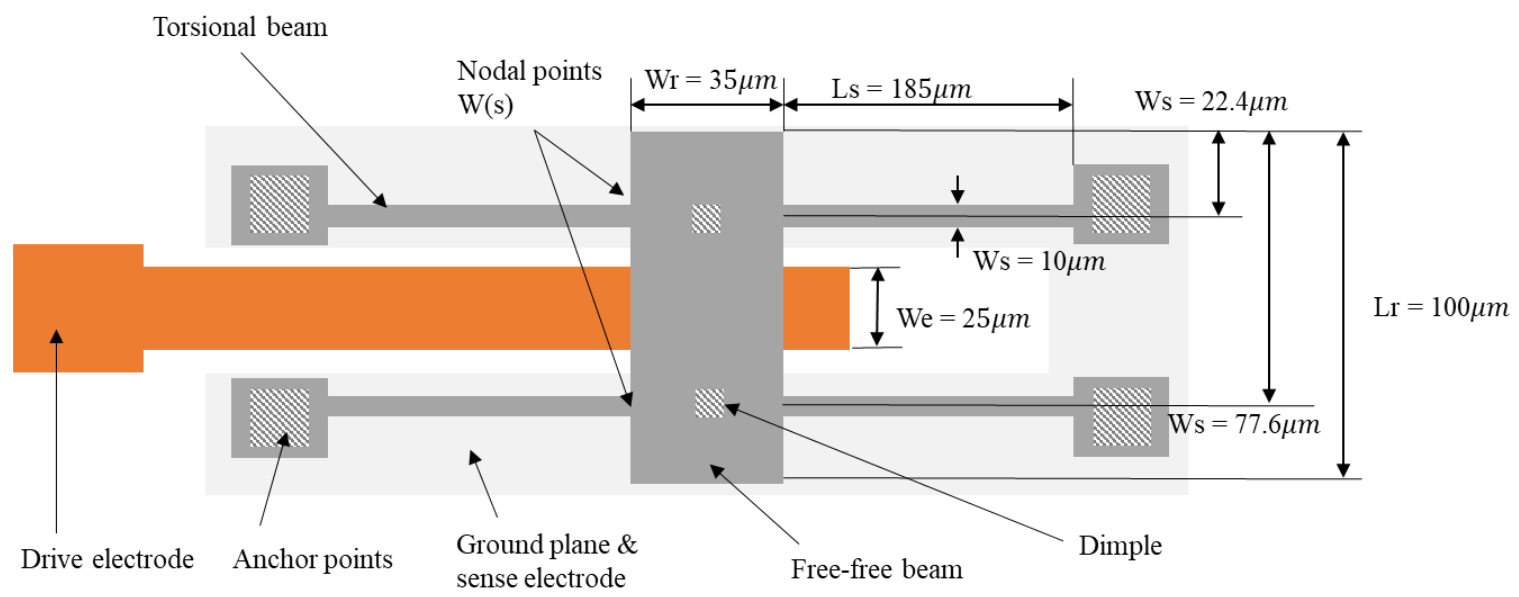

Gambar 5. Kalkulasi desain resonator free-free beam.

\subsection{Aktuasi dan Penginderaan}

Gaya elektrostatik dibuat dengan menerapkan tegangan DV Vdc antara struktur resonator dan elektroda aktuasi di bawah struktur untuk membangkitkan perangkat. Eksitasi input IC menginduksi osilasi resonator pada frekuensi (Vac)in. Keluaran yang dihasilkan adalah arus keluar yang dinyatakan dengan [10]:

$$
i_{\text {out }}=V_{d c} \frac{\partial C}{\partial t}=V_{d c} \frac{\partial C}{\partial z} \frac{\partial z}{\partial t}
$$

Dimana $\mathrm{z}$ adalah perpindahan dalam arah vertikal dan $\partial \mathrm{C} / \partial \mathrm{z}$ adalah perbedaan kapasitansi per satuan perpindahan antara balok berosilasi dan elektroda aktuasi.

Free-free beam mulai berosilasi pada amplitudo maksimumnya sehingga $\mathrm{C} / \partial \mathrm{z}$ memiliki nilai terbesar ketika frekuensi Vin mencapai frekuensi alami resonator. Resonator dimaksudkan untuk berosilasi dalam mode pertama seperti yang dinyatakan dalam persamaan (4) sehingga tegangan input harus diatur sedemikian rupa sehingga eksitasi tidak berpindah ke mode kedua atau mode yang lebih tinggi. Metode pembacaan atau penginderaan untuk resonator terdiri dari kapasitor yang terhubung pada ground plane dan sense electrode.

Ketika tegangan DC besar diterapkan antara resonator dan elektroda, seluruh struktur ditarik dan terbebankan pada dimple. Ketika dimple berada dalam kondisi ini, celah elektroda ke resonator akan cukup kecil untuk memberikan kopling elektromekanik [22]. Celah kapasitor transduser kemudian tergantung pada ketinggian dimple $\left(\mathrm{g}_{\mathrm{o}}\right.$ ) alih-alih lapisan sacrificial yang ketebalannya $\mathrm{g}_{\mathrm{ini}}$. Harus diperhatikan bahwa tegangan bias DC harus cukup untuk menurunkan resonator ke dimple, tetapi masih cukup kecil untuk menghindari pull-down lebih lanjut setelah dimple turun. Dengan menaikkan tegangan akan terjadi kondisi tertentu dimana kestabilan kesetimbangan hilang dan balok jatuh ke substrat, yang disebut fenomena pull-in $\left(\mathrm{V}_{\text {pull-in }}\right)$. Vdc harus lebih kecil dari Vpull-in tetapi lebih besar dari Vdimple. Persamaan untuk Vdimple diberikan [22]:

$$
V_{\text {dimple }}=\sqrt{\frac{8}{27} \frac{k s \cdot g_{\text {ini }}^{3}}{W r \cdot W e}}
$$

Dimana $k s$ adalah E.Ws $(T r / L s)^{3}$. We adalah lebar elektroda yang ditentukan oleh desain yang ditetapkan pada $25 \mu \mathrm{m}$ dan $W r$ adalah lebar berkas resonator $(35 \mu \mathrm{m})$. Jika nilai $g_{i n i}$, yaitu nilai celah awal telah ditetapkan, maka Vdimple dapat dihitung.

Ketika free-free beam diaktuasi, struktur tertarik ke bawah dan menyentuh substrat yang diilustrasikan pada Gambar 6. 


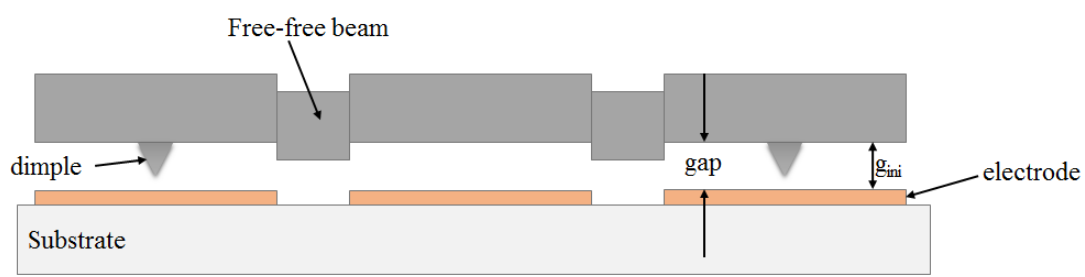

(a)

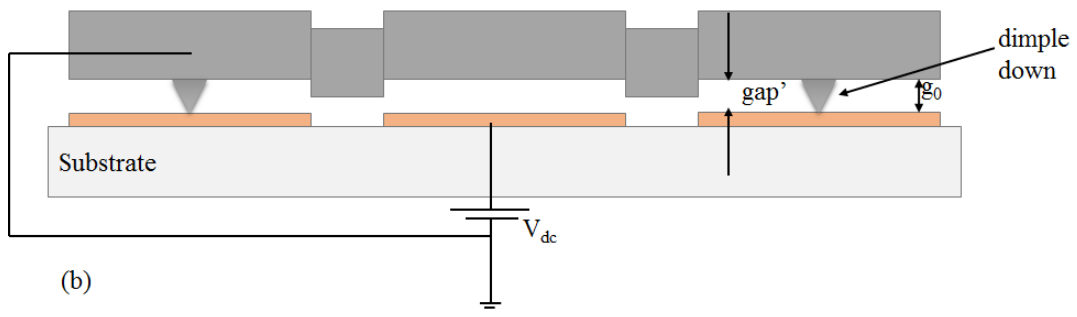

Gambar 6. Ilustrasi Penampang celah kapasitor yang diaktifkan secara elektrostatis (a) setelah fabrikasi dan (b) setelah tegangan DV diterapkan.

Memanfaatkan dimple untuk mengatur celah kapasitor memberikan beberapa keuntungan seperti tegangan DC yang lebih rendah karena jarak celah tergantung pada lesung pipit terlepas dari ketebalan lapisan pengorbanan, tidak ada penarikan bencana, dan faktor kualitas yang lebih tinggi dibandingkan dengan resonator balok klem ganda [21].

\subsection{Analisis Resonator Massa Bergerak}

Resonator free-free beam menawarkan jangkauan dinamis tinggi dan penanganan daya. Keuntungan lain termasuk resistansi gerak seri yang lebih rendah dan beberapa port yang memungkinkan pergeseran fasa input-to-output nol [23]. Struktur ini juga memungkinkan faktor kualitas frekuensi yang lebih tinggi yang akan berguna jika diterapkan dalam komunikasi frekuensi radio.

Desain untuk resonator khusus ini lebih rumit dibandingkan dengan balok kantilever sederhana. Titik simpul harus dihitung seperempat panjang gelombang untuk mempengaruhi transformasi impedansi yang mengisolasi berkas bebas bebas dari jangkar kaku. Hanya jika impedansinya nol, resonator dapat beroperasi secara efektif karena melayang tanpa dukungan [22]. Selain itu, ketebalan resonator tidak dapat ditentukan secara pasti oleh desain. Hal ini lebih tergantung pada proses fabrikasi.

Membandingkan resonator ini dengan resonator akustik, resonator mekanik telah ada di pasaran selama bertahun-tahun. Ini adalah teknologi yang lebih matang sehingga menawarkan biaya yang lebih murah. Resonator SAW memiliki potensi besar untuk dikembangkan. Prinsip kerja perangkat akustik SAW lebih sederhana dibandingkan dengan resonator yang diusulkan dalam makalah ini. Perangkat SAW tidak melibatkan prinsip mekanis seperti defleksi, lentur, atau berputar sehingga tidak aus dan harus lebih tahan lama dan andal. Namun biaya pembuatan alat ini lebih mahal dibandingkan dengan resonator mekanik.

Finite element analysis (FEA) software dapat digunakan untuk memvalidasi desain yang sudah dibuat. Sensor yang sudah didesain dapat dimodelkan dengan menggunakan software FEA dengan memasukkan semua parameter yang sudah didapatkan. Respon resonator terhadap aktuasi elektrostatik dapat divalidasi menggunakan simulasi eletromekanik. Selain itu, juga dapat dilakukan modal analysis untuk mengevaluasi karakteristik getaran yang dihasilkan dari desain yang dibuat.

\section{KESIMPULAN}

Pada penelitian ini, telah dilakukan perancangan resonator MEMS untuk penginderaan massa. MEMS merupakan perangkat elektro-mekanik yang bergetar pada frekuensi tinggi dan telah diterapkan untuk berbagai aplikasi. Pendekatan yang digunkan dalam desain adalah resonator mekanik karena teknologi yang ditawarkan lebih matang daripada resonator akustik. Dari berbagai struktur yang tersedia (kantilever, terjepit, dan free-free beam), dipilih struktur free-free beam karena walaupun desain ini lebih rumit, performa yang dihasilkan juga lebih tinggi. Sensor yang dirancang ini akan diaktuasi secara elektrostatis. Perancangan sensor ini diharapkan dapat menghasilkan kualitas $Q$-factor yang tinggi. Untuk ke depannya, desain ini dapat difabrikasi dan dilakukan pengukuran respon untuk mengevalusi seberapa presisi desain teoritis yang sudah dibuat dengan respon sensor secara eksperimental. Penelitian lebih lanjut mengenai kehandalan, siklus hidup, dan stabilitas sensor perlu dievaluasi secara menyeluruh agar MEMS dapat diaplikasikan dan diterima secara lebih luas. 


\section{DAFTAR PUSTAKA}

[1] J. W. Gardner, V. K. Varadan, and O. O. Awadelkarim, Microsensors, MEMS, and smart devices. John Wiley \& Sons, Inc., 2003.

[2] Y. Development, "MEMS industry: the headwindsfrom COVID-19 and the way forward," ed, 2020.

[3] Z. Zhou, Z. Wang, and L. Lin, Microsystems and nanotechnology. Springer, 2012.

[4] B. E. DeMartini, J. F. Rhoads, M. A. Zielke, K. G. Owen, S. W. Shaw, and K. L. Turner, "A single input-single output coupled microresonator array for the detection and identification of multiple analytes," Applied Physics Letters, vol. 93, no. 5, p. 054102, 2008.

[5] Y. Kessler, S. Krylov, and A. Liberzon, "Flow sensing by buckling monitoring of electrothermally actuated doubleclamped micro beams," Applied Physics Letters, vol. 109, no. 8, p. 083503, 2016.

[6] C. Zhao et al., "A resonant MEMS accelerometer with 56ng bias stability and 98ng/Hz 1/2 noise floor," Journal of Microelectromechanical Systems, vol. 28, no. 3, pp. 324-326, 2019.

[7] N. Li, C. Xing, P. Sun, and Z. Zhu, "Silicon-Glass-Silicon Triple Stacked Structure for Fabrication of MEMS Resonator Accelerometer," in 2019 20th International Conference on Electronic Packaging Technology (ICEPT), 2019: IEEE, pp. 1-4.

[8] H. Zhang et al., "A high-performance mode-localized accelerometer employing a quasi-rigid coupler," IEEE Electron Device Letters, vol. 41, no. 10, pp. 1560-1563, 2020.

[9] L. Xu, S. Wang, Z. Jiang, and X. Wei, "Programmable synchronization enhanced MEMS resonant accelerometer," Microsystems \& Nanoengineering, vol. 6, no. 1, pp. 1-10, 2020.

[10] V. Kumar et al., "Bifurcation-based mass sensing using piezoelectrically-actuated microcantilevers," Applied Physics Letters, vol. 98, no. 15, p. 153510, 2011.

[11] J. Mouro, R. Pinto, P. Paoletti, and B. Tiribilli, "Microcantilever: Dynamical response for mass sensing and fluid characterization," Sensors, vol. 21, no. 1, p. 115, 2021.

[12] T. Rabenimanana, V. Walter, N. Kacem, P. L. Moal, and J. Lardiès, "Nonlinear analytical model of two weakly coupled mems cantilevers for mass sensing using electrostatic actuation," in Multidisciplinary Digital Publishing Institute Proceedings, 2018, vol. 2, no. 13, p. 1084.

[13] E. Martínez-Cisneros et al., "Analytical modeling of mechanical behavior for MEMS/NEMS-based single-clamped multilayer resonators with symmetrical complex shapes," Microsystem Technologies, vol. 27, no. 5, pp. 2167-2182, 2021.

[14] L. Li, Y.-p. Zhang, C.-c. Ma, C.-c. Liu, and B. Peng, "Anti-symmetric mode vibration of electrostatically actuated clamped-clamped microbeams for mass sensing," Micromachines, vol. 11, no. 1, p. 12, 2020.

[15] F. Nabki, T. A. Dusatko, and M. N. El-Gamal, "Microelectromechanical resonators for RF applications," in Wireless Technologies: CRC Press, 2017, pp. 589-628.

[16] H. Campanella, Acoustic wave and electromechanical resonators: concept to key applications. Artech House, 2010.

[17] V. K. Khanna, Nanosensors: physical, chemical, and biological. CRC Press, 2019.

[18] T. Zhang, "Electrostatic free-free beam microelectromechanical resonator," 2012.

[19] Z. J. Davis, W. Svendsen, and A. Boisen, "Design, fabrication and testing of a novel MEMS resonator for mass sensing applications," Microelectronic Engineering, vol. 84, no. 5-8, pp. 1601-1605, 2007.

[20] J. Wang, "Theoretical analysis and design of a double-clamped microchannel resonator," Massachusetts Institute of Technology, 2007.

[21] C.-C. Nguyen, "Micromechanical resonators for oscillators and filters," in 1995 IEEE Ultrasonics Symposium. Proceedings. An International Symposium, 1995, vol. 1: IEEE, pp. 489-499.

[22] K. Wang, A.-C. Wong, and C.-C. Nguyen, "VHF free-free beam high-Q micromechanical resonators," Journal of microelectromechanical systems, vol. 9, no. 3, pp. 347-360, 2000.

[23] M. U. Demirci and C.-C. Nguyen, "Higher-mode free-free beam micromechanical resonators," in IEEE International Frequency Control Symposium and PDA Exhibition Jointly with the 17th European Frequency and Time Forum, 2003. Proceedings of the 2003, 2003: IEEE, pp. 810-818. 